
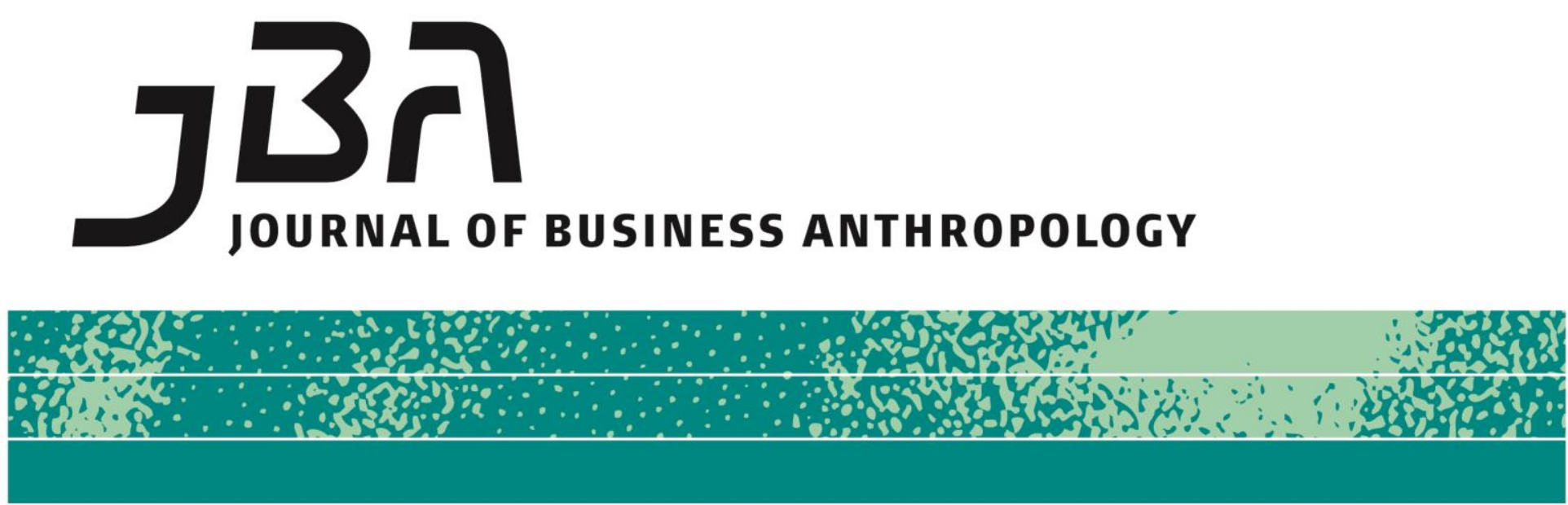

\title{
Of Old and New Business Ethics: How Fair Trade Becomes Patronage and Paternalism in a Darjeeling Tea Plantation
}

Arnaud Kaba

\begin{abstract}
This paper is about Fair Trade and business ethics. It analyses data from fieldwork conducted in a famous Darjeeling tea plantation which practices biological and biodynamic farming and is labeled as Fair Trade. Its aim is to show how the plantation owner, using aggressive marketing of his engagement with eco-friendly and corporately-responsible management, has managed to regenerate an old patronage system more or less similar to industrial paternalism, but with its roots in colonial as well as indigenous domination structures. Disappointed by their unions, workers have had no alternative but to accept this form of governance, and some even acknowledge it as a good one. This case is a good example of how Fair Trade, which claims to empower workers, can be used to fuel a system which results in their disempowerment as social actors.
\end{abstract}

Page 1 of 20

JBA Special Issue 3: 20-39, Spring 2016

(C) The Author(s) 2016 ISSN 2245-4217

www.cbs.dk/jba

\section{Keywords}

Fair Trade, labor, patronage, business ethics, tea plantations, neoliberalism 


\section{Introduction}

Numerous authors have stressed the contradictions that revolve around the concept of Fair Trade, because it is a network of producers, NGOs and suppliers trying to establish what they view as a fairer commercial system while using the globalized market economy to do so (Cary 2004; Diaz-Pedregal 2007). ${ }^{1}$ This double bind has sometimes been regarded as a "dance with the devil" (Jaffee 2007). Daniel Jaffee denounces the fact that this system of exchange, normally reserved for petty producers, has now been transposed to plantation work, thanks to the labeling organizations, ${ }^{2}$ which are attempting to protect not just the small peasant, but now a waged workforce (ibid.). For example, according to Paul Luetchford (2007), who studied the Fair Trade impact on petty coffee producers in Costa Rica, the results seem rather positive overall, despite some issues related, for example, to the employment of seasonal wage laborers. The problematic fact of translating this kind of system to a waged workforce is that the notion of Fair Trade, born around the 1940s, once relied heavily on international solidarity networks created by Christian activists, often Mennonites (Jaffee 2007) or Marxists (DiazPedregal 2007), because its main idea was to introduce fairer relationships between the small producers from the South and consumers from the North by establishing direct contact between them. Of course, the intermediaries were seen as the source of the oppressive nature of the relationship. After the creation of Max Havelaar, the first labeling organization, in 1988, two opposite visions emerged: one, sometimes called the "revolutionary" vision, which wanted to rely only on the "old" small activist networks; and the second, the "reformist" vision, which wanted to generalize the selling of Fair Trade Products through the labeling system, albeit in supermarkets (Diaz-Pedregal 2007). It is the reformist vision which seeks to transfer the Fair Trade system to waged work. More broadly, Gavin Fridell (2010) argues that the Fair Trade network is indeed compatible with neoliberal institutions and that, to empower southern farmers, it has to set its actions within State policies instead of implementing programs that seek to replace the state welfare policies, thereby becoming an alibi for neoliberal institutions' claim for economic deregulation. ${ }^{3}$

\footnotetext{
${ }^{1}$ This article is based on a talk that was mainly a presentation of a book chapter on entrepreneurial ethics (Kaba 2015) and is largely inspired by this publication in French.

2 Before the rise of these labels, the fair trade associations used to buy directly from petty producers with whom they had a direct link (Cary 2004). Creating labels allows suppliers to obtain products from any producer and so makes the product's origins harder to discover. Moreover, the evaluation of the "fairness" practiced by the producer's management remains at the labeling organization's discretion.

${ }^{3}$ The fieldwork used as the basis for this paper was conducted in a Fairtrade Darjeeling tea plantation, broadly during 6 months, from 2009 to 2010. I was home staying in the plantation as a tourist, and I conducted my research with the planter's authorization but also under his observation.
} 
The analysis presented in this article is polemical in two senses: first, because I discuss a fair trade tea plantation that makes use of an agricultural workforce, and because socio-economic and anthropological studies of tea plantations hitherto have viewed them as a neocolonial (Chatterjee 2001), or even imperialist (Chausuri 1995), exploitation system; and second, because I studied a plantation labeled by the Fair Trade Labelling Organization (FLO) ${ }^{4}$ which has been criticized by Daniel Jaffee (2007) and Paul Cary (2004) for its ambiguous position regarding the modes of distribution (for example, the choice to supply supermarkets, and even Starbucks). In this sense, therefore, this particular plantation is a company practicing a "merchandizing of ethics" (Gallenga 2013). It sells partly ethical goods, because the consumer who buys its products thinks $s /$ he is making an ethical gesture that justifies the price.

According to Sarah Besky, an American anthropologist who has already conducted fieldwork in this plantation, the social situation there, though not bad, mainly consists in appliance of the law (with some corner cuts) but, more importantly, the democratic bodies meant to defend a worker's rights are indeed controlled by the planter, and are in a sense eroding the power of the unions which are responsible for the law's appliance (Besky 2008). In these respects, Fair Trade could be seen as a neoliberal alibi allowing the planter to sell directly to importers, while also shortcutting the legal framework by being certified as having "fair" labor practices without having to deal with the State labor institutions (Besky 2010)-an analysis that confirms Fridell's hypothesis (2010).

Given what has already been said, I will not here focus so much on Fair Trade certification issues as such, but analyze the way entrepreneurial ethics ${ }^{5}$ contained in the company's marketing discourse copes with its actual management practices and ethics. In this regard, the company presented in this paper presents a sharp contradiction between the marketing discourses aimed at consumers and suppliers, which emphasizes ecological and socially-responsible management of the company, on the one hand, versus its actual management system, which in many aspects looks like a patronage system, on the other. This does not mean that the planter is avoiding all his social responsibilities: he is indeed redistributing some part of his capital in the form of social advantages to his workers; but the mode of distribution and the ethics behind it are very different. This mode of distribution looks like a kind of paternalism that reflects pre-industrial relationships, but which still has extensive influence in almost every hierarchical relationship in South Asia. Specifically, it involves a patronage system, or a set of relationships

\footnotetext{
4 The Fair Trade Labeling Organization is an NGO putting together, in a single network, twenty labeling organizations such as Trans Fair USA and Max Havelaar.

5 "Entrepreneurial ethics" is a complex and contradictory concept which can fit many senses (Gallenga 2013). In this article, I use it in the strict sense of a set of values meant to guide a company's management.
} 
based on protection against services.

Thus, a number of questions arise. How does the company produce a discourse based on corporate social responsibilities, at the same time as being based on worker's empowerment, so as to satisfy its clients (suppliers, customers, labeling organizations)? How can the planter implement social benefits that are, indeed, inferior to those mandated by Indian law; and are any claims made against him by his workers as a result? What kinds of social movements have been generated by this situation? Did the planter use the social benefits claimed and obtained by the unions to establish a paternalism structured by the kind of clientelist system that is so typical of that found in South Asia between dominants and subordinates?

In the first part of this article, I will explain how the planter develops a discourse that conforms to the ethical model conveyed by the labeling organizations, and will show how it interacts with the actual governance of the plantation. I then discuss breaches in the company's social responsibilities, especially in regard to the Indian law and worker's demands. I will show that it is indeed the workers, through their unions, who have brought about most of the social advances in the plantation's management, but that the trade union movement finally declined because of the planter's authority, as well as internal tensions. In the last part, I will show how the planter regained monopolistic control over social issues in the plantation by using an external discourse, which enabled him in a more coercive way to consolidate a traditional clientelist system that had formerly existed in this and other plantations.

\section{A cooperative in the marketing discourse: centralized and authoritarian governance}

The plantation discussed in this article is situated in the Darjeeling district (West Bengal, India). The domain, more than 500 hectares in size, includes, aside from the tea bushes, numerous spaces covered with forests, and seven villages, inhabited by more than 2000 people. Many of them work inside the plantation, although this is not an absolute rule because the plantation cannot absorb everyone in its workforce and because educated young people tend to migrate out to seek better employment elsewhere. Almost all the workers are of Nepalese origin, as is a huge majority of the population as a whole in the Darjeeling district. Surrounded on its eastern side by the Nepalese and Chinese borders, this district has been populated by migrant workers and soldiers brought here by the British. They are is commonly identified as "Gurkha," an old name for Nepalese people coming from the eighteenth century Nepalese empire, and staking a claim for a separate State, the Gurkhaland, for almost a century now (Samantha 2000).

The plantation practices biodynamic agriculture and is certified by 
"Demeter."6 It is also certified as a Fair Trade plantation and offers ecotourist homestays. One of its unique features is that a single planter owns the land, since nowadays, in many plantations, the planter is only the plantation's manager, while the land is often owned by private funds and companies. It is thus not necessary for the planter to have an intimate link to the soil he is managing: he is ultimately a boss, appointed by the merchants. In this case, however, the plantation is family owned, perpetuating a father/son transmission model: the plantation was one of the first to be managed by Indians in the Darjeeling district, back in 1859. Since that time, the owners of the plantation have been born on this very soil-a fact which, unsurprisingly, the planter refers to when advertising his "terroir" on his website, ${ }^{7}$ alongside an ecological discourse based on his desire to regenerate the soil. The rhetoric of terroir, however, is not a particularity of this plantation: following the steps of the Cognac producers, the planter is an amateur in marketing the quality of his plantation's soil in order to sell his tea as a high-priced luxury good (Besky 2010).

The last heir of his lineage (his sons are not interested in the tea business), the owner has perpetuated the pioneering initiatives of his forebears, being the first plantation in Darjeeling district to convert to biological farming, a conversion that was not especially costly, as the amount of pesticides used in the Darjeeling plantations had never been high (Besky 2008). Furthermore, the choice to engage in biodynamic farming makes his plantation a rather unique case, even in a context where biological farming is becoming more and more successful (Besky 2010). The planter's marketing discourse advantage makes the most of these choices on a well-furnished internet site presenting numerous articles on the presumed originality of his ecological project, which he claims to have imagined after a mystical revelation following a fall from a horse. The plantation also markets its ethical side, presenting the workers' rights provided and the overall wish to help their empowerment-especially those of women. The planter presents his management plan in a holistic view of the plantation that deals with ecological, economic and social challenges.

His tea is also marketed, of course, with an argument for its quality: some years ago, it was the most expensive tea in India, and was therefore considered the best. There is also an autobiographical book written by the planter about his tea estate and the way he manages it, together with two documentaries and some advertising material given to visitors by the staff. However, the main way that the tea is marketed is through direct contact with importers, who are the main intermediaries between the planter and retail outlets, both in India and in the rest of the world. This is a specificity of the Fair Trade system, since otherwise the planter would

\footnotetext{
${ }^{6}$ An organization certifying biodynamic exploitations.

${ }^{7}$ As this paper in anonymized, I cannot give the references of the internet site or of any advertising documents from the company.
} 
have to sell his tea by way of a broker and the tea auction system in Kolkata, which acts as a financial center for tea exchange. There I saw him negotiating with Indian and European importers. He also hosts them, visits the plantation with them, and tries to weave personal ties with them. He is, for example, a close friend of his main French importer and knows well another smaller French importer, who also made a documentary about the plantation with another friend. So the tea's marketing is here based principally on personal relationships, and the marketing discourse somehow merges with the personality and charisma of the planter, who is by reputation a great story-teller. This very personal marketing was, so far as I understood, the main means by which he managed to present his holistic management model as a communitybased model and as a unique development project. This is a vision which copes well with the way Fair Trade is often perceived by its actors: a (relatively) direct, ethical (in the sense that the money is "fairly" redistributed to the producers), ecological, and community (often cooperative)-based economic exchange (Jaffee 2008; Cary 2004). Therefore even without looking at the actual plantation's management, one can see a sharp contradiction between the discourse itself (emphasizing the community) and the method used to spread it (a very personalized one).

Like the tourists and the importers, I was also in contact with this discourse during my numerous encounters with the planter. And I have to admit that the latter did a very good job in advertising his plantation-so well, indeed, that his French importer friend told me once that he seemed to have a magical power in the way that he charmed people. During my stay there, I was part of a tourist program normally conducted by the plantation (consisting of volunteering to do schooling, agricultural, or medical work), but as long as I was paying for my stay, I was tolerated as a "tourist researcher." I did participant observation and worked in the tea processing factory, where the workforce is generally composed of men, and in the tea field, where women are in the majority. This rule is common to all tea plantations (Chatterjee 2001; Bhowmick 1984). I also observed workers' daily and family lives. My data also include informal discussions, as well as formal interviews and narratives, conducted with unionists, regular workers, and politicians. As I was not a Nepali speaker, I was dependent on an informant's network, and, during the second year of fieldwork, on a translator who had to put up with some pressure from the planter who, after having read quite displeasing articles about his management, was wary of young researchers interviewing union members.

The fieldwork conducted on this plantation revealed that although the planter sought to present it as a cooperative, the organization of labor had much the same hierarchical, postcolonial structure of any other plantation. There are four grades of foremen (the higher the grade, the more workers and lower foremen one can supervise), then division 
directors (the factory is then considered as a division), a general director, and a planter. This is exactly the pyramidal structure of every tea estate since the colonial times (Bhowmick 1984; Chatterjee 2001; Sharma 2000, 2005). There, the foreman's authority is far from being absolute. On many occasions I have seen women workers answering back to their forewoman. Thus discipline is by no means Spartan: in the fields, women negotiate sharply over their break, while in the factory, men often show up for work half an hour late and take a lot of informal breaks. However, these kinds of informal daily resistance are common in India and do not indicate an absence of exploitation (De Neve 2005). The harsh work, especially in the fields, leaves no doubt about this. Furthermore, although the employees are from the formal sector, there is nothing like the "shirking" ambience that Parry observed in the steel complex of Bhilai (Parry 1999). It is also important to note that my fieldwork was conducted during spring, when production is low and there is not much tea to pluck or process. According to my informants, coercion for extended and quicker work was far greater during the high season in summer (from June onwards). During that period, there is a lot of tea to pluck, and as the laborers obtain some extra wages when they have harvested extra weight, they will often discipline themselves to earn a bit more income.

If we consider the staff, authority lies clearly in the planter's hands. According to my informants, he takes all the important decisions and other members of staff have only a managing role. Thus, during staff meetings, which took place in the administrative building hall, the foremen would sit on the side on some benches while ordinary staff members sat on their bottoms in the rear of the hall, while the general director and the planter sat at a desk in the middle. But the planter had a much better-looking chair and the most central position. The scene resembled a king's council, with the planter/king in the middle with his chancellor to one side, the ministers behind him, and his court in front. At least, this is how popular Hindi TV shows represent it.

A colorful character, the planter looks like he had just come off a TV screen-but from another type of show, a nostalgic and extremely popular series about the colonial era. With his khaki jacket and shorts, his hat (though not the colonial pith helmet) and his horse, which he loves to ride when touring the plantation, he is indeed the perfect incarnation of a gentleman farmer. He has studied in the UK, and loves to bring the tourists (or importers) to his cottage, inviting them in with a charming British accent. He then feeds them with stories about his family and his own achievements, along with some biodynamically-produced miso soup. ${ }^{8}$ Not only does this planter, with a Bengali background, ${ }^{9}$ obtain

8 The miso soup is made from vegetables needing a lot of water to grow, even though workers' villages experience a huge scarcity of water.

${ }^{9}$ Although it been established in the plantation, the family's roots are in Kolkata. 
symbolic status with this image; he is also a Brahmin, and his nickname means "king." So he could hardly carry with him more symbols of power: the colonial administrator and the king of his domain, belonging furthermore to the higher caste status. So his stature of absolute power obviously contradicts the vision he would like to promote as simple manager of a community for which, as stated in the internet site (while explaining why the tea estate is fair and ethical, and using the "we" pronoun): "We sustain the right of the community for health, housing, education, but also to decide on its future with self-confidence and sovereignty"-guided by the mantra of "partnership, not ownership." Nor does it make credible his personal discourse when he sometimes calls himself a "small farmer" in front of the tourists. He indeed owns not only half the hill where his forests and tea bushes grow, but also (as in any plantation) the very soil upon which all the inhabitants' houses are built. His omnipresence is also perceptible in the laborers' discourse since he features in almost every single one of their conversations. The workers can express their attachment, their disgust, their recognition through their anger, but, however they do so, the planter remains central. When referring to the authority inside the plantation, the workers almost never talk about the managers, directors, or other staff, but about him directly. His decisions seldom encounter resistance, even though breaches in workers' rights are numerous.

\section{Breaches in social standards}

Surprisingly, for a plantation which claims to engage itself in favor of workers' rights, their empowerment, and community management-in other words, which claims to do more than what is compulsory-there are a number of breaches in mandatory labor rights as outlined in Indian law. In addition, the premium provided by the sale of Fair Trade products should in theory be reinvested in "community projects" (Nichols and Opal 2005). The organization in charge of deciding how the income is to be reinvested into such projects is called the Joint Body. It is thus a compulsory element for any enterprise wishing to export goods labeled "fair trade." When Fair Trade actors were still dealing only with cooperatives, the Joint Body was the council of each cooperative's members. Their goal was to decide democratically where people who own their means of production should reinvest their surplus income (ibid.).

Since plantations like the one under discussion are now labeled "fair trade," the Joint Body is made up of workers' representatives, but how are these representatives chosen? This is not openly made clear by those concerned. Interestingly, the plantation's website does make a reference to the "Joint Body" which is now (although this was not the case at the time of my fieldwork) described as a continuation of the village's elder councils, which managed to handle "for over a century the wellbeing of their respective villages." The management is then presented as an institution which is approached for help when an issue is beyond the Joint 
Body's control. In the plantation, as Besky already noted, the Joint Body has only a representative role, mainly for the benefit of tourists, NGO representatives, and customers who ask to meet it. I was told during my fieldwork that the last Joint Body meeting had been held three years previously. Similarly, when Sarah Besky arrived some years before me, she was also told that the Joint Body had not met for months (2008). Hence, there is no clear evidence that the Joint Body has ever met in any other form than a decorative one. For example, during my stay, a fake meeting was held for visiting Swedish students. This was more an interview, during which the translator was obliged to invent a discourse when the Joint Body members-mainly women, because the plantation pretends to act for gender emancipation-were asking themselves what they should say to these foreigners. They had received no orders from the planter and feared his reaction if they said anything wrong. The questions about money which were raised by the students had to be avoided, and for advice they turned to the General Director.

This is not to say that no community projects exist. They do, but except when-as we will see later-they are implemented by tourists or foreigners, it is the planter who is the president of this Joint Body-normally a consultative position-and, according to all my informants, he is the one who takes all the decisions, sometimes alongside his staff. An old Joint Body member, who can be seen on the internet site as a "the sole member of the NAP-Council of Fairtrade Labelling Organisation, who has carved a niche for herself in the annals of Fair Trade international representation for all Tea Estates lady workers globally," told me quite directly that they had no autonomy, although she had defended some proposals, for micro loans for example, that had been successful. But, again, other informants told me that it was generally the planter who decided which personnel could and could not obtain loans. The proposals she was talking about were old ones from the 1990s, when, according to my informants, the Fair Trade system was functioning in a much better way.

At the time of my fieldwork, there were also breaches in the application of compulsory labor rights, this is to say, of the laws that all plantations-"fair trade" or not-should uphold. Being a part of the Organized (labor) Sector, the tea plantation workers are part of the tiny minority of laborers (seven per cent, according to Lerche 2012) who are protected by Indian labor laws, especially by the Plantation Labor Act of 1951. The first and the most notable of the rights provided by this act is that it is practically impossible to dismiss a worker, who is also sometimes allowed to bequeath his job to his son at the time of his retirement. This right was broadly respected on the plantation. Workers have a minimum wage (which also exists in the unorganized sector) and diverse allowances: for example, the right to have their houses repaired free of charge (since the planter owned them), the refunding of medical expenses, help for children's schooling, and some basic living materials. 
Although Besky (2008) noted that the daily wage was slightly below the minimum at the time of her fieldwork, during my own research the company was respecting the minimum wage. Medical expenses were sometimes refunded, usually after several years of delay, but sometimes not at all. It was somehow ironic that one of the main activities of the tourists was to participate in the health care volunteer program, on a plantation where the company should have been making donations for healthcare-at least, for all those in the plantation labor force. The repair of houses was erratic, and often carried out by the tourists themselves, who paid around fifteen euros a day for their stay, and who purchased materials and contributed their labor to help the villagers repair their houses-this on a plantation where, except for the (rare) houses where no one worked inside the tea gardens, house repair should have been at the management's expense. This situation tends to occur especially in a context where tea gardens' minimum wages are extremely low, partly because all these allowances are calculated as part of those wages. Thus, when in 2010, I entered the Darjeeling planters club to obtain documents and explanations about minimum wages in the plantations, I was told that the remarkably low paid salary of Rs $67^{10}$ per day was such because the workers' real wage when allowances were included was above Rs 200 per day. ${ }^{11}$

The laborers, and the villagers in general, experienced an acute water scarcity problem, which stimulated their anger (as water provision is also compulsory according to the law on Plantation Labor Rights). It is true that this is not specific to the plantation and that it is an endemic issue throughout the Darjeeling district (Banerjee 2010), but it was especially severe inside the plantation. Thus, families from the plantation had to walk an average of 20 minutes every day in order to reach the springs, where they had to load around 30 liters of water per person in order to supply their household. One should keep in mind that this is a mountainous area, so that this task was particularly exhausting for them.

10 To compare: in my actual Bhopal fieldwork, where people worked in the informal sector, the daily wage for unskilled to skilled workers ranged from Rs 50 to Rs 250/300, while extra-skilled workers could earn up to Rs 500/600 on heavy working days. But, at the same time, being part of the Organized Sector, the tea plantation workers were considered to be included in what Parry calls an "aristocracy of labor." So one has to understand that, contrary to other sections of the Organized Sector where wages are significantly higher than in the informal sector (ibid.), their only advantage lies in the stability of their employment and their allowances. I do not make a conversion or rupees into euros or dollars because, although it is amusing to see that Rs 62 comes to less than two dollars a day, with Max Havelaar declaring that " 1 billion people are earning less than 2 dollars a day," and that Fair Trade is meant to solve this kind of problem, such statements do not mean anything, except that they highlight the global repartition of capital because they are not linked with the local economy. In Darjeeling, if you earn the local minimum wage, and if you have a permanent job with your allowances properly given, you can live a somehow poor but pretty decent life compared to local standards.

${ }^{11}$ For example, when the "rental" price of the laborer's house is taken into account. 
The few waterworks that were constructed were built by tourists, especially by a British visitor who raised funds from the Rotary Club, and by an American couple who built a community center through the NGO CARE. Again, this means basically that these benefactors used to pay almost ten times the laborer's wage in homestay in order to carry out at their own expense what the planter himself should have done. Almost half the sum was given back to the host family, the other half to the Joint Body (in other words, as stated earlier, to the company). This made hosting tourists a great opportunity for tea plantation inhabitants.

All these breaches of the law are obviously not specific to this plantation. Failure to respect the Plantation Labor Act is common in the Darjeeling district (Sharma, 2000, 2003, 2005), and many informants stated that the situation on the plantation was acceptable, but not especially better than on any other plantation. ${ }^{12}$ Besky (2008) also came to the same conclusion. Therefore, the so-called corporate responsibility of the plantation is indeed a simple (and imperfect) respect of the law in terms of social benefits. We should not assume that the rights given to these workers by the owner reflect an effort to obtain Fair Trade certification, or are due to the kind of personal initiative presented on the internet site. The owner's father was practically expelled from the plantation by his workers who, following mobilization in the late 1970s, established a union against his will and fought for their rights. The present planter had to manage a transition of power from father to son at a time of heavy social tension. It was under pressure from the first plantation union-a CITU trade union (Center of Indian Trade Unions) affiliated to the Communist Party of India (Marxist) ${ }^{13}$ - that the main social improvements were made during the 1980s. Many workers were given permanent positions, before being later dismissed in the low production period-something which is now impossible, and which further explains the low rhythms I witnessed while doing fieldwork during the low season. Houses were improved, and the first school built on the plantation. Previously, the children had to walk an hour in order to attend school in the neighboring town of Kurseong. The 1980s saw fratricidal struggles between leftist and regionalist unions (affiliated with the Gorkha National Liberation Front, a party that advocated a separate Gorkhaland state). According to my informants, this conflict deeply compromised the relationships between trade unions in all plantations in the district. Shooting incidents between communists and regionalist trade union members are said to have occurred. The planter's French importer

\footnotetext{
12 They made this estimation based on what they were told by their family members and friends on the neighboring plantations. The unionists also made use of their trade union network to form judgements.

13 The Communist Party of India (Marxist), founded in 1964, was born from a schism with the Communist Party of India and is one on the main leftist parties in India. It used to be extremely powerful in West Bengal, and kept power there for more than 30 years (1977-2011) before being wiped out by Mamata Banerjee's Trinamool Congress.
} 
friend explained to me that during this period, he used always to walk around the plantation carrying a loaded gun. It thus appears that from both the planter's as well as the workers' perspectives, this period was one of considerable tension, approaching some kind of collective trauma.

Following this, the introduction of Fair Trade and several revelations concerning corruption scandals involving trade unionists, ${ }^{14}$ the involvement of workers in union militancy decreased inside the plantation. Today, the only remaining union had only 50 members in 2010 and seldom received support from the workers. Many believe that union members, some of whom evolved from being leftists to regionalists, are active only for the advantages that their position can give them vis-àvis the company and that, during negotiations with the staff, they will call on the planter to conclude a friendly agreement. Today, people often prefer to approach the planter or other staff members directly when they want to get a loan or to raise an issue of some sort. The last noticeable victory by the union was over the issue of Nepalization of the workers in the 1990s, when staff positions, previously allocated only to Bengalis, were partly opened up to people of Nepalese origin, born on the plantation. The only other issue that the union had recently negotiated-putting aside the continuous pressure to maintain wages following the regular raise of the minimum wage-has been the rehabilitation of houses following the cyclone in 2009 and some more recent landslides.

It would be tempting to postulate a link between the decline of the unions, the end of the Soviet Union, and India's entry into an era of globalization through the liberalization of its economy-all of which occurred in 1991. But we should not draw such a conclusion before understanding the particularities of Indian labor conditions, which, according to Rohini Hensman (2011), have little to do with globalization as such, being more aggravated by neoliberalism rather than caused by it. This means that one should be cautious before linking a case study presenting poor labor conditions and low trust in trade unions to recent changes at international and national levels. For example, the Communist Party stayed in power until 2011 in West Bengal, twenty years after the decline of the communist unions in the Darjeeling district, a situation that seems to have been caused more by an inability of the communists to address regionalist claims than by anything else.

Another point has to be made about the unions. I agree with Besky (2008) when she concludes that Fair Trade institutions, though they pretend the opposite, are acting in this case as neoliberal institutions competing against and threatening to erode the state-driven unions and legal institutions, which were already protecting the workers quite well on this plantation. I have every reason to believe that this might be the

${ }^{14}$ For example, two scandals involved the union, as well as the planter, when funds from NGOs for villages' water connections were embezzled. 
case throughout the Darjeeling district. Fair Trade was seen by Darjeeling's planters as a way to expand their market and gain more flexibility with labor issues, being able to cut corners on labor laws without losing their certification (ibid.). In this sense, the link between Fair Trade and neoliberalism seems quite obvious. We have seen that in this plantation, the Fair Trade institutions allow the planter to market his product as a socially responsible tea, as he respects a law that would never have been respected without the trade union movement,. However, these institutions do not seem keen to support any efficient institution representing the labor force's interests (as we have seen with the Joint Body's inactivity). It is also important to stress the high level of corruption that sometimes occurs within the unions, including the union on this plantation. Such corruption has contributed to their loss of credibility much more rapidly than the creation of Fair Trade institutions. Of course, Besky (2010) says that people are nostalgic for the old welfare model and even the colonial times, which they view-not necessarily correctly-as an era with less corruption. I myself suspect that the nostalgia of the Darjeeling inhabitants is a fictive representation of a Golden Age, to help them deal with the trauma of bloody political rivalries of the 1980s, and may well be exaggerated. This may also be true of the discourses I collected about the early days of the union.

Corruption within Indian unions is hardly new and has probably no link with neoliberal policies or globalization. Based on his fieldwork in the nationalized coal mines of Dhanbad in the early 1980s, Heuzé (1987) stated that the miners did not trust their unions because they saw them as dishonest and clientelist. Miners sought union assistance only because they could obtain some sort of personal benefit for themselves or family members from the union. These workers, as Marxists, also operated under the illusion of a Golden Age embedded in a nostalgia for a fantasized village economy (ibid.). Moreover, the discourse centered on the recent upsurge in corruption is popular in other parts of India and may be exaggerated (Parry 2000).

Having dealt with these controversial points, let us now come back to the figure of the planter and try to understand how he was able to regenerate an old governance system through the use of clientelist relationships with his workers.

\section{A management system regenerating an old clientelist structure}

Prior to the creation of the trade union, the planter's father ran the plantation paternalistically, in a manner described by Chatterjee (2001): the planter had to represent a strong authority, with a bit of benevolence (the plantation already had a dispensary at that time), so as to be both strict and just. Thus, an old retired worker told me that he was nostalgic for the era of the planter's father, when the workers were "innocents" (that is, not yet inspired by Marxist ideologies) and when governance was 
"fair" (it did not encourage shirking activities through a too lax position). There was also good social mobility at that time. A man started as a teenage tea plucker and ended his career in a good supervisor position. This kind of governance is characterized as a patronage ${ }^{15}$ system by Chatterjee (ibid.), a relationship that presupposes obedience and deference on the part of a worker, and a mix of coercion, sense of justice, and even protection on that of the owner. This image derives from images of the colonial administrator and the Mughal Empire landlord called a zamindar. ${ }^{16}$ The planter was often called the Maa-Baap, ${ }^{17}$ the fathermother figure or supreme authority. The planter based his authority on coercion (the father's side), but he was also a protective figure (the maternal side), which allowed him to convince his workers that he wishes them well. This governance system, applied by the current plantation owner, has obtained an implicit charter of values, an ethos of the dominant. It is also impossible to deny that the current planter allowed for significant social progress on his plantation, especially compared to the administration of his father. He agreed to negotiate with the unions, to implement social protection, to regularize the status of almost all the workers as permanently employed, and to implement some "community development" projects, although many of these failed or were started by external actors. Finally, he opened up staff positions to the locals.

Nevertheless, the governance system has remained the same in essence. Thus, the female member of the Joint Body mentioned earlier referred to the planter as "their mother and father." In this sense, the owner stays completely within the Maa-Baap image: he is ostensibly distant from his employees, obliging them to salute him military-style whenever he visits the plantation-an act which could hardly be clearer

\footnotetext{
15 This kind of relationship, as we will later see, should not be totally confused with paternalism. Rather, it is a specific form of patron/client relationships which, even today, frame a large number of hierarchical relationships in India: for example in political parties (Rudolf 1998), pre-independence village life (Dumont 1969; Breman 1996), and even the structure of unions (Ramaswamy 1983; Chatterjee 2001). It was present even more in pre-revolutionary Nepal (Ramirez 2000). So this kind of relationship is a general pattern that exists in diverse forms, embedding distinct realities.

16 The zamindars were the local landlords of the Mughal Empire, consisting broadly of a class of petty or medium countryside nobility often coming from the lineages of village chiefs. They were used by the empire as intermediaries to collect the huge amount of land taxes fueling the Mughal war machine. Their power was conserved during British dominion, when administrators somehow imitated the domination system of the zamindars, particularly in how they also (partly) established their control over land revenues, thereby including themselves in indigenous domination structures.

${ }^{17}$ The Maa-Baap figure in an evocation of colonial power. As a patronage system, it has multiple forms-referring to the State as a protective entity, or to the colonial administrator himself. Here, it is a reference to the figure of the administrator: the first planters, who were British, were like the administrators of their domains. In many plantations, the situation has evolved socially, of course, but little has changed concerning the nature of this power relationship (Chatterjee 2001; Sharma, 2000).
} 
concerning the weight of the colonial legacy. He can be very harsh with his workers at times, and acts as their benefactor only if they also exhibit the required amount of deference and obedience. The owner's protection is thus quite different from positive labor rights since obtaining any sort of material or social benefit is always seen as a favor. Workers who have the most difficulties obtaining their refunds are generally those who did not act deferentially enough when requesting these refunds from the planter, or who are part of the trade union and do not accept his overtures of co-optation. The micro loans, so much advertised on the company's Internet site, are not given by the Joint Body, but have to be requested directly from the general director or the planter. The union is also trying to pressurize the staff in order to obtain more loans, but when it comes to health benefits, the workers often prefer to ask for these themselves, thus developing a personal-and, of course, very unequal-relationship of dependence with the planter. Workers who are not docile fear the planter, and there are many rumors about "traitors" and "spies" (generally those who have obtained larger loans, time benefits, or the opportunity to host tourists) who are said to report any subversive statement to the planter. To what extent this is true I do not know for sure, but during fieldwork, the planter consistently demonstrated to me that he was well-informed of my progress and of my (potentially subversive) "findings."18

The practice of granting loans is by no means a contemporary social measure implemented by Fair Trade actors and NGOs. The loans may have a new name-"micro loans"-but, in fact, granting one-off loans for weddings, funerals, or to buy some drinks has been a very old practice among the colonial planters, and was originally used to tie the workers to the plantation when money-lenders' interest rates were exorbitant and debts almost impossible to repay (Engels [in Robb 1993]; Xaxa 1997; Bhowmick 1981; Chausuri 1995; Chatterjee 2001). This system was not specific to tea plantations, and in the whole of rural India loans made by the dominant class are still used to acquire land and sometimes to put the dominated groups into bonded labor positions (Breman 1974, 1985; Heuzé 1989; Picherit 2009). Therefore, the use of micro loans to perpetuate an old practice of moneylending is not specific to this fieldwork or to the tea plantations. Picherit (2009) observes how in Andra Pradesh (now Telangana), the Reddys, a cast of landowners, middlemen and moneylenders, have managed to acquire a monopoly on the micro loans officially attributed to them, thus giving formal borrower status to people who already owe them informal loans. The planter does not bond anyone by the debt because the interest he demands, around three per cent, is more than reasonable compared to the interest rates in the informal moneylender system (where rates for informal loans can

18 Therefore I must thank him for not having expelled me from his plantation when he knew very well that my survey had come to reveal information that could be harmful to his company's image. 
easily be as much as 30 per cent). Still, as the loans are not granted on formal, democratic terms, but by a unilateral act of benevolence, the planter's micro loan arrangement reproduces this patronage system, in a somehow more benign way. This could be interpreted as paternalism, but it should be linked with an older colonial and indigenous genealogy of Indian modes of domination.

Interestingly, the planter now assumes this genealogy, and states on the plantation's home page (though presenting these characteristics as the management's):

The management-since its inception in 1859-has always done its best to augment or resolve a crisis that threatened the harmonious functionality of the community. This bond had always been the cornerstone for the bonding between the generations of the Chatterjees ${ }^{19}$ and the resident working community.

While this mode of governance certainly contradicts claims by the company to work for the empowerment, social rights, and selfdetermination of the community, it does not necessarily contradict the planter's idea of a holistic community whose functionality he helps to keep intact in harmonious fashion. As I said, this mode of governance has some of its roots in indigenous patronage systems. Hence, these systems reproduce an ethos coming from the Hindu hierarchical ideology-an ideology which is precisely based on a holistic vision of society which, contrary to Fair Trade proponents and to Western modern ideology, consists of hierarchical and unequal relationships between its members. Western modernist conceptions envision a community formed of equal members, at least from an ontological point of view (Dumont 1967). For Dumont, the jajmani system, which ruled the economic exchanges and power relationships in the villages, came from that ideological framework. Although this point is controversial, it is difficult to deny that there is at least some reference to the ethos of the Hindu (Brahmanical) rank hierarchy in the way patronage relationships are shaped (Heuzé 1987). It should be noted here that the planter and his family are Brahmins, which would make them particularly influenced by this Brahmanical ideology. From this point of view, there is not much contradiction between the Fair Trade conception of community-oriented welfare and management, the holistic conception of nature from the biodynamic agriculture, and the Brahmanical ideology. What is missing from this equation, of course, is any notion of workers' empowerment!

If the planter has managed to reproduce a governance system against which his workers have in the past rebelled, it is probably because he has also managed to take back social issues from the union's hands. For their part, a huge majority of the workers are resigned and cynical. They have no more confidence in the union leaders, or in the promises of Fair Trade. Some speak of the 1970s and1980s as a Golden Age for the

19 The family name has been changed. 
union, with the beginning of Fair Trade certification. But, for many workers, hope for social justice vanished a long time ago. The majority are resigned to soliciting the benevolence of the planter, instead of defending their rights in some kind of labor struggle. This is not to say that they are unaware of the submission their attitude implies, or of the illegal nature of the situation: my interpretation is that, as with the corruption scandals and their internal struggles, the unions have failed to come up with an alternative vision. The workers feel that they hardly have a choice. Whenever I raised these issues, the response was invariably one of "What can we do?"

As he regenerated his soil thanks to permaculture, the planter could also regenerate his paternalist patronage-partly because of the Fair Trade neoliberal institutions; partly because of the foreign tourists and benefactors who funded his system of targeted and somehow authoritarian benevolence. By taking on an ersatz ethical position vis-àvis the outside, mainly for marketing reasons, the planter was able to regenerate his own kind of ethical governance. But the ethics here is paternalist, based on the protection of the obedient worker in this system.

The corporate social responsibilities within the plantation are not exactly what they are supposed to be when presented to the outside world. The workers, even those most frustrated by the planter's governance over their lives, recognize that he is a good businessman who can maintain the plantation's finances by profitably exporting his goods to the entire world. With the Fair Trade strategy, the planter thus performs his first obligation of protection: keeping the plantation and the workers' jobs out of danger.

\section{Conclusion}

This model will probably soon come to an end. The owner recently sold his garden to a holding company, and he now owns only ten per cent of the shares. His sons will not take back the plantation, but he is still the general manager (Nyogi 2014). Having myself not returned to the plantation in six years, I do not know exactly how the decision to sell was taken by the planter, although there were rumors at the time of my fieldwork about his intention to do so. However, following the discussion above, I have every reason to believe that this paternalistic model would have survived a long time if the planter's sons had taken over the estate.

As we have seen, Fair Trade certification, with its neoliberal vision of the workers' rights, probably helped the owner sell his tea at a higher profit, while providing him with a tool with which to deal with the social issues within the plantation in an old, clientelist planter's way. It even enabled him to maintain some breaches in his application of the labor law.

The planter's adaptability was not the only factor behind his success, however. Divisions resulting from regional political evolution, and the unions' involvement in corruption, led to the latter's loss of 
credibility. I would, however, be very cautious before concluding which factor is the more salient or if the two are linked. Nevertheless, we have described how an older system of governance, with roots in colonial and indigenous domination, was regenerated by internal modernization and CSR-friendly marketing which provided it with discretionary funds in the form of micro loans. We have seen how "traditional" modes of governance can be dramatically competitive and extremely resilient, even in a context where supposedly new corporate social responsibilities are promoted.

Finally, it seem clear that the labeling organizations who supply this tea in the Western world by labelling it "Fair Trade" have, probably unintentionally, allowed for the marketing of more expensive tea while sacrificing workers' empowerment. Fueling the system with the extra money collected, the plantation has benefited from the Fair Trade system, but undermined its workers' ability to demand and receive more and better labor rights. But this is hardly surprising, given that the confrontation of Fair Trade ideals with local business ethics is essentially one of abstract ideologies, sometimes denounced as too abstract (Besky 2008), with norms that are primarily pragmatic and functional (Gallenga 2013). Business ethics, as we have seen, can be developed not in order to be "fair," but rather to manage the workforce more efficiently.

\section{References}

Banerjee, R. 2010. Rumble in the hills. Darjeeling Times, 2 (4).

Besky, S. 2008. Can a plantation be fair? Anthropology of Work Review 29 (1): 1-9.

Besky, S. 2010. Colonial pasts and fair trade futures: changing modes of production and regulation on Darjeeling tea plantations. In Sarah Lyon and Mark Moberg (eds.), Fair trade and social justice: global ethnographies. New York: NYU Press, 97-122.

Besky, S. 2014. The labor of terroir and the terroir of labor: geographical indications and Darjeeling tea plantations. Agriculture and Human Values 31(1): 83-96.

Bhowmick, S. 1981. Class formation in plantation systems. New Delhi: People's Publishing House.

Breman, J.C. 1974. Patronage and exploitation, Berkeley. University of California Press.

Breman, J.C. 1985. Of Peasants, migrants and paupers. Delhi: Oxford University Press.

Cary, P. 2004. Le commerce équitable: Quelles théories pour quelles pratiques? Paris: l'Harmattan.

Chatterjee, P. 2001. A time for tea: women, labor and post-colonial politics 
on an Indian plantation. Durham: Duke University Press Books.

Chaushuri, A. 1995. Enclaves in a peasant society: political economy of tea in Western Dooars in Northern Bengal. Delhi: People's Publishing House.

De Neve, G. 2005. The everyday politics of labor. Delhi: Social Science Press.

Diaz Pedregal V. 2007. Le commerce équitable dans la France contemporaine: idéologies et pratiques. Paris: L'Harmattan.

Dumont, L. 1967. Homo hierarchicus: essai sur le système des castes. Paris: Gallimard

Fridell, G. 2010. Fair trade, free trade, and the state. New Political Economy 15 (3): 457-470.

Gallenga, G. 2013. L'éthique entrepreneuriale: un objet anthropologique? Moussons 21: 21-36.

Hensman, R. 2011. Workers, unions, and global capitalism: lessons from India. New York: Columbia University Press.

Heuzé, D.G. 1989. Ouvriers d'un autre monde: l'exemple des travailleurs de la mine en Inde contemporaine. Paris: Editions de la Maison des Sciences de l'Homme.

Heuzé D. G., 1987. Travail ouvrier et consciences communautaires: l'évolution des mentalités des travailleurs de la mine en Inde contemporaine. Cahiers des Sciences Humaines 23 (2): 245-260.

Jaffee, D. 2007. Brewing justice: fair trade coffee, sustainability, and survival. Berkeley: University of California Press.

Kaba, A. 2011. Les réalités du commerce équitable: l'exemple d'une plantation de Darjeeling. Paris: l'Harmattan.

Lerche, J. 2012. Labour regulations and labour standards in India: decent work? Global Labour Journal 3 (1): 16-39.

Luetchford, P. 2007. Fair trade and a global commodity: coffee in Costa Rica. London: Pluto Press.

Nicholls, A. and C. Opal 2005. Fair trade: market driven ethical consumption. London: Sage Publications.

Parry, J. 1999. Lords of labour: working and shirking in Bhilai. Contributions to Indian Sociology 33 (1-2): 107-140.

Parry, J. 2000. "The crisis of corruption" and "the idea of India": a worm's eye view. In I. Pardo (ed.), The morals of legitimacy. New York and Oxford: Berghahn Books, 27-55.

Picherit, D. 2009. Entre villages et chantiers: Circulation des travailleurs, clientélisme et politisation des basses castes en Andra Pradesh, Inde. Thèse de doctorat. Paris: Universtité de Nanterre.

Ramaswamy, U. 1983. Work, union and community. New Delhi: Oxford 
University Press.

Robb, P., 1993. Dalit movements and the meaning of labour in India. Delhi: Oxford University Press.

Rudolf, L. and S. Rudolf 1998 (1987). In pursuit of lakshmi: the political economy of the Indian state. Chicago: The University of Chicago Press.

Samanta, A.K. 2000. Gorkhaland movement: a study in ethnic separatism. New Delhi: APH Publishing Corporation.

Sharma, K. 2000. The Himalayan tea plantation workers. Dibrugarh: N.L. Publishers.

Sharma, K., 2003. Tea Plantation workers in a Himalayan region. New Delhi: Mittal Publications.

Sharma, K. 2005. Sociology of Indian tea industry. New Delhi: Mittal Publications.

Arnaud Kaba is a PHD candidate in social anthropology at EHESS (Toulouse), and is currently completing his thesis about the professional cultures and proletarian consciousness of the informal metal workers of Bhopal, India. He is at present assistant lecturer in Aix Marseille University and can be reached at arnaud.kaba@gmail.com. 